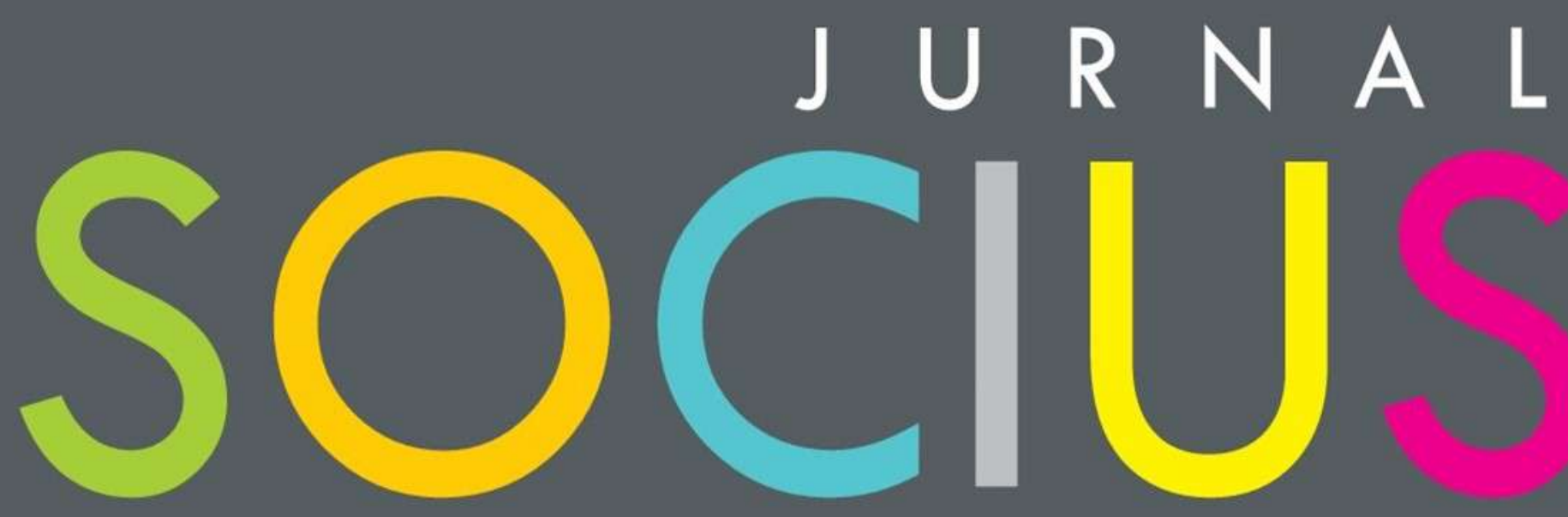

Journal of Sociology Research and Education

DITERBITKAN OLEH :

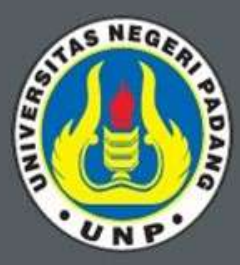

LABOR JURUSAN SOSIOLOGI FAKULTAS ILMU SOSIAL UNIVERSITAS NEGERI PADANG

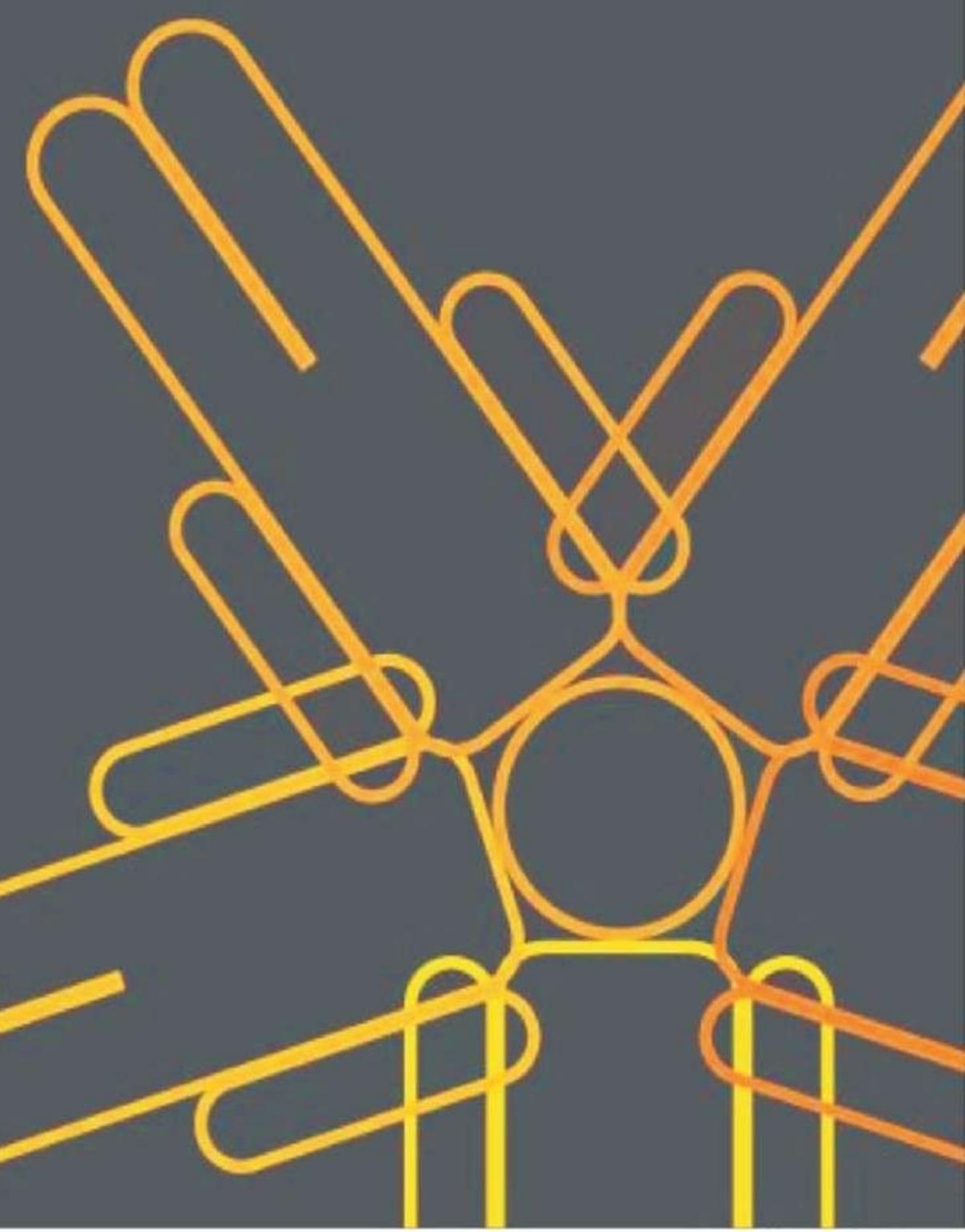




\section{SOCIUS}

Vol. 7, No. 1, Th. 2020

ISSN : 2356-4180 (cetak)

2442-8663 (online)

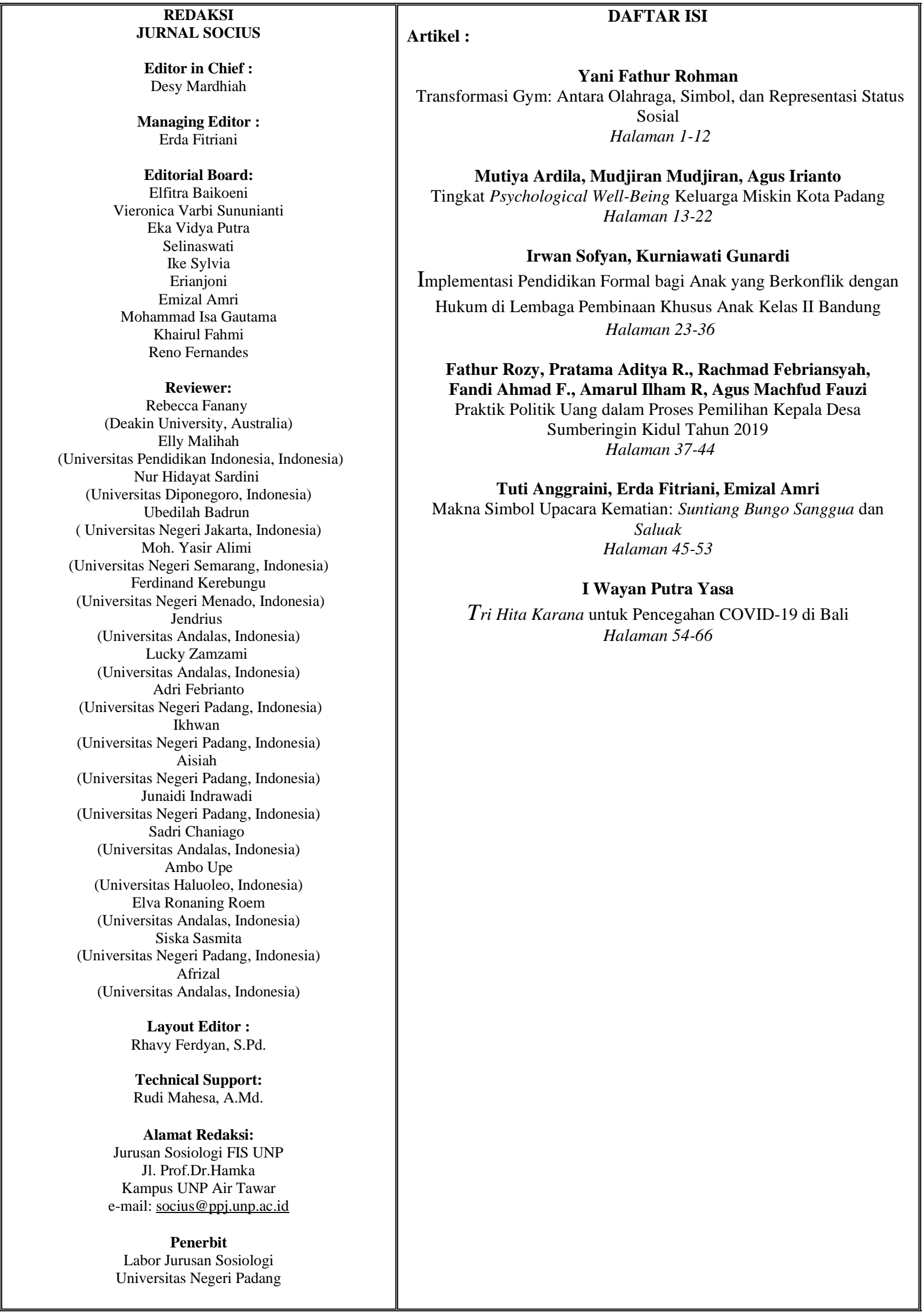




\title{
Praktik Politik Uang dalam Proses Pemilihan Kepala Desa Sumberingin Kidul Tahun 2019
}

\author{
Fathur Rozy ${ }^{1}$, Pratama Aditya $R^{2}$., Rachmad Febriansyah ${ }^{3}$, \\ Fandi Ahmad F. ${ }^{4}$, Amarul Ilham $\mathbf{R}^{5}$, Agus Machfud Fauzi ${ }^{6}$ \\ ${ }^{123456}$ Universitas Negeri Surabaya \\ Email: fathurrozy799@gmail.com
}

\begin{abstract}
Abstrak
Pilkades merupakan suatu ajang yang digunakan untuk menyeleksi calon Kepala Desa yang akan memimpin suatu desa dalam jenjang waktu tertentu. Dalam pelaksanaanya Pilkades sering diwarnai dengan beberapa bentuk kecurangan seperti salah satunya politik uang. Penelitian ini dilakukan dengan tujuan untuk mengungkap dan mengetahui terjadinya fenomena politik uang yang terjadi di dalam proses pemilihan kepala desa. Penelitian ini dilakukan dengan perspektif teori fenomenologi dari Alfred Schutz. Penelitian ini mengunakan metode penelitian kualitatif guna mendapatkan informasi yang mendalam dan mendukung proses analisis. Metode pengumpulan data dalam penelitian ini meliputi observasi, wawancara dan dokumentasi. Sumber informan adalah masyarakat yang memiliki hak pilih pada Pilkades. Penelitian dilakukan di Desa Sumberingin Kidul, Kecamatan Ngunut, Kabupaten Tulungagung. Hasil dari penelitin ini adalah kontestasi politik di Desa Sumberingin Kidul ditemukan praktik politik uang. Hal ini menunjukkan bahwa kesadaran akan pentingnya kontestasi politik yang sehat masih belum melekat di dalam tubuh masyarakat.
\end{abstract}

Kata kunci: Desa, Pemilihan, Pilkades, Politik Uang

\section{Abstract}

Pilkades is an event that is used to select a village head who will lead a village at a certain time. Implementation the Pilkades is also often characterized by several forms of fraud such as money politics. This research was conducted with the aim to uncover and find out the phenomenon of money politics that occurred in the village head election process. This study using the phenomenological theory of Alfred Schutz for analyzing the problem. This study uses qualitative research methods to obtain in-depth information and support the analysis process. Data collection methods observation, interviews and documentation. Informants are taken from people who have the right to vote in the Pilkades event. This research was discovered that political contestation used to money politic in Sumberingin Kidul Village, Ngunut Sub-District, Tulungagung District. This shows that awareness of the importance of healthy political contestation is still unembeded in society.

Keywords: Election, Money Politics, Pilkades, Village

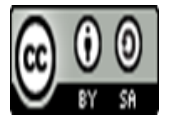




\section{Pendahuluan}

Pilkades atau pemilihan kepala desa merupakan praktik kontestasi politik pada tingkat pedesaan. Adapun yang terlibat baik sebagai penyelengara, peserta, dan pemilihnya adalah warga desa itu sendiri. Sama dengan Pemilu yang lainnya, Pilkades diselengarakan secara langsung dan serentak. Sepanjang tahun 2019 terselenggara sebanyak 235 Pilkades di Kabupaten Tulungangung, Jawa Timur (Ardianto, 2018). Diselengarakan serentak pada tanggal 9 Juli 2019, dengan pembiayaan sebanyak 15 milliar rupiahyang bersumber dari APBD (Susanto, 2018).

Masyarakat pedesaan sudah terbiasa dengan peyelengaraan pemilihan umum secara langsung. Minimal dalam lima tahun, masyarakat pedesaan mengikuti empat kali pemilu, yakni pemilu legislatif, pemilihan presiden dan wakil presiden, pemilihan gubernur dan wakil gubernur serta pemilihan bupati/walikota dan wakil bupati/walikota. Keterlibatan masyarakat dalam pemilu di atas sebagian besar lebih sebagai pemilih. Dalam jumlah dan kewenangan terbatas beberapa masyarakat terlibat menjadi penyelengara atau tim sukses. Secara keseluruhan, isu yang selalu hangat pada setiap penyelenggaran Pemilu adalah isu politik uang (Damsar, 2010). Banyak ahli mengistilahkan praktek politik uang dengan kentut, ia terbaui tapi tidak tahu sumber dari bau tersebut (Maran, 2007). Menarik untuk melihat dalam penyelenggaraan Pilkades tidak hanya sebagai pemilih atau penyelenggara tapi juga sebagai peserta. Dalam konteks budaya politik, apakah dalam penyelengaraan Pilkades juga ditemui ada praktek politik uang? Menarik untuk melihat bagaimana kontestasi tersebut terjadi pada masyarakat pedesaan yang memiliki ciri gemeinschaft.

Persoalannya adalah pelaksanaan Pilkades serentak yang ada di Kabupaten Tulungagung ini tidaklah selalu berjalan dengan mulus tetapi terdapat kendala-kendala teknis dalam berbagai bentuk kecurangan-kecurangan. Salah satunya yakni kecurangan dalam bentuk politik uang. Misalnya pada Pilkades di desa Sumberingin Kidul, Kecamatan Ngunut ini. Beberapa calon kepala desa saling berlomba-lomba untuk memberikan politik uang guna menarik simpati dari warga masyarakat sekitar. Sebagaimana diketahui adanya politik uang didalam proses pemilihan umum yang sesungguhnya sangat bertentangan dengan Undangundang No. 3 Tahun 1999 Pasal 73 ayat 3 mengenai pelarangan praktik suap menyuap pada saat pemilihan umum (Mahfud, 2019) .

Proses pemilihan kepala desa yang ada di Desa Sumberingin Kidul, Kecamatan Ngunut ini menghadirkan dua orang calon yaitu calon nomor urut pertama bernama Arianto yang merupakan calon petahana dan ditantang calon nomor urut ke dua bernama Saifuddin. Menjelang proses pemilihan, kedua calon tersebut saling berlomba-lomba untuk meraih dukungan dan simpati dari masyarakat desa. Salah satu cara yang digunakan untuk menarik simpati tersebut yakni dengan cara memberikan politik uang kepada masyarakat. Politik uang yang diberikan oleh kedua calon kepala desa ini memang bagaikan sebuah perlombaan politik. Dalam penelitian ini, peneliti berusaha menggali dan mengungkap lebih dalam lagi mengenai fenomena praktik politik uang dalam proses Pilkades di desa Sumberingin Kidul, Ngunut, Tulungagung.

Untuk menganalisa fenomena tersebut, peneliti menggunakan perspektif teori fenomenologi dari Alfred Schutz. Fenomenologi itu sendiri menurut Schutz merupakan suatu tindakan yang dilakukan oleh manusia dapat menjadi suatu hubungan sosial bila manusia saling dapat memberikan arti ataupun sebuah makna tertentu terhadap suatu tindakan yang telah dilakukanya. Tindakan sehari-hari yang dijalankan oleh setiap individu di muka bumi ini pada dasarnya memiliki tujuan yang hendak dicapai yang kemudian hal ini oleh Schutz disebut dengan In Order to Motive. Schutz juga berasumsi jika dunia keseharian merupakan 
suatu pengalaman yang sarat dengan nilai makna, dengan begitu fenomena yang tampak dari seorang individu merupakan suatu refleksi dari pengalaman yang bersifat transedental dan pemahaman mengenai makna atau jika dalam bahasa Weber disebut dengan verstehen. Tindakan subjektif yang dilakukan oleh para aktor sejatinya tidak muncul dengan begitu saja melainkan melalui sebuah proses yang cukup panjang dengan memperhatikan kondisikondisi sosial, ekonomi, budaya dan norma-norma atas dasar tingkat kemampuanya sendiri sebelum tindakanya dilakukan (Fahmi, 2018) .

Dalam penelitian ini penulis menggunakan beberapa acuan penelitian terdahulu diantaranya yakni penelitian Haili dengan judul "Praktik Politik Uang Pemilihan Kepala Desa". Penelitian ini menggunakan metode penelitian kualitatif deskriptif. Adapun hasil penelitian ini yakni praktik politik Pilkades berlangsung melalui beberapa cara seperti pembelian ratusan kartu suara dengan harga yang cukup tinggi, pembagian uang kepada masyarakat secara langsung, serangan fajar dan penggelontoran uang secara besar-besaran secara sporadis oleh timses paslon masing-masing (Haili, 2009). Kemudian penelitian yang mengungkap perilaku politik uang di Pariaman, Sumatera Barat. Hasil penelitian ini menyimpulkan bahwa money politics dilakukan hampir oleh semua calon legislatif. Politik uang dilakukan dengan berbagai cara, seperti uang tunai, bantuan untuk organisasi, bantuan infrastruktur, dan sebagainya (Putra, 2018).

Penelitian dengan judul "Politik Uang Pemilihan Kepala Daerah di Desa Ketapang dan Desa Tanjung Kulim Kabupaten Kepulauan Meranti. Penelitian ini menggunakan metode penelitian kualitatif dengan pendekatan deskriptif. Adapun hasil dari penelitian ini adalah ditemukan banyak faktor yang menyebabkan terjadinya money politics seperti salah satunya faktor ekonomi masyarakat yang tidak dapat menghindari terjadinya politik uang dan adanya kekurangan pengetahuan publik mengenai visi misi dari Paslon yang mencalonkan diri. Selain itu karena tidak adanya kesadaran politik dan rendahnya kepercayaan publik dari Pemerintah (Nuratika, 2015). Selanjutnya penelitian dengan judul "Politik Uang dalam Pemilihan Kepala Desa (Studi Kasus di Desa Jatirejo, Kecamatan Banyakan, Kabupaten Kediri”. Penelitian ini menggunakan metodologi kualitatif dengan pendekatan studi kasus. Penelitian ini juga turut menggunakan teori strukturasi dari Anthony Giddens sebagai pisau analisis. Adapun hasil penelitian ini ditemukan beberapa bukti praktik-praktik politik uang yang dilakukan oleh tim sukses kandidat kepala desa. Adapun cara yang dilakukan untuk menyalurkan politik uang adalah melalui kegiatan kampanye. Sedangkan wujud dari politik uang adalah berupa uang tunai, pemberian barang dan pemberian janji-janji politik seperti pembangunan infrastruktur dan ziarah wali bersama (Amanu, 2015).

Penelitian dengan judul "Tindak Pidana Politik Uang Pemilihan Kepala Desa dalam Perspektif Hukum Positif dan Hukum Islam (Studi Kasus di Desa Magonten Kec. Kebonagong Kab. Demak). Penelitian ini dilakukan dengan menggunakan metode kualitatif deksriptif. Adapun hasil dari penelitian ini yakni proses Pilkades yang ada di desa Megonten Demak sudah memenuhi unsur-unsur pidana, adanya segala bentuk pemberian uang, barang dan fasilitas umum oleh calon Kepala Desa Megonten kepada para calon pemilihnya termasuk ke dalam unsur yang dilarang hukum dan telah melanggar Undang-undang Nomor 10 Tahun 2016 tentang Pilkada (Mukhsinin, 2018).

Dari beberapa penelitian terdahulu yang telah dikaji di atas, sebagian penelitian yang telah ada pada pembahasan di atas kebanyakan masih berfokus pada proses-proses terjadinya praktik money politics serta bentuk-bentuk pemberian politik uang. Tidak hanya itu dalam penelitian sebelumnya juga sudah ada yang membahas mengenai tindak pidana dalam proses politik uang. 
Oleh karena itu dalam penelitian ini, peneliti menjadi terinspirasi untuk mengetahui proses terjadinya praktik politik uang beserta fenomenanya berdasarkan motif sebab serta motif tujuan dan peneliti juga turut memfokuskan penelitian pada persepsi masyarakat mengenai praktik politik uang beserta antusiasme masyarakat mengenai praktik politik uang, selain itu dalam kajian ini masih belum pernah dikaji menggunakan persepektif fenomenologis Schutzian.

\section{Metode Penelitian}

Penelitian ini menggunakan metode penelitian kualitatif yang bersifat deskriptif. Penelitian deskriptif kualitatif merupakan salah satu jenis penelitian yang berusaha untuk memahami dan menggambarkan fenomena yang sesungguhnya dialami oleh subjek penelitian yang dalam hal ini dialami oleh masyarakat desa yang pada saat itu turut memiliki hak pilih. Adapun lokasi penelitian yakni di lingkungan desa Sumberingin Kidul, Ngunut, Tulungagung. Sebagai fokus kegiatan untuk memperoleh data mengenai fenomena praktik politik uang dalam proses pemilihan kepala desa di Desa Sumberingin Kidul.

Dalam penelitian ini yang menjadi subjek utama penelitian yakni para warga masyarakat desa Sumberingin Kidul, khususnya bagi mayarakat yang memiliki hak pilih pada saat Pilkades dan juga turut mendapat politik uang dari pasangan calon kepala desa. Subjek penelitian tersebut dipilih dengan tujuan agar peneliti dapat memperoleh informasi yang terkait dengan penelitian secara mendalam dan terperinci. Penelitian ini menggunakan dua buah sumber data yakni data primer dan data sekunder. Data primer merupakan sebuah data yang diperoleh secara langsung dengan cara turun lapangan yakni dengan cara pengamatan (observasi), wawancara secara mendalam bersama para informan dan dokumentasi. Sedangkan data sekunder yang digunakan dalam penelitian ini bersumber dari berbagai artikel jurnal, buku, ataupun berbagai informasi dari internet. Dalam penelitian ini digunakan teknik analisis data menurut Milles dan Huberman dimana terdapat tiga tahap dalam proses analisis datanya yang pertama yakni reduksi data. Pada tahapan ini, hasil wawancara dengan informan dilakukan penyederhanaan. Tahap kedua yaitu melakukan penyajian data. Penyajian data dilakukan dengan tujuan untuk mempermudah peneliti dalam melakukan penarikan kesimpulan dan menggambarkan secara menyeluruh. Tahap yang terakhir yaitu penarikan kesimpulan. Dari kedua teknik di atas, penarikan kesimpulan dilakukan dengan cara mencari inti dari analisis data berdasarkan data dari informan. Suatu hasil analisis yang menggambarkan hasil dari penelitian dapat digunakan untuk mengambil suatu keputusan.

\section{Hasil dan Pembahasan}

\section{Hasil Penelitian}

\section{Proses Pemilihan Kepala Desa Sumberingin Kidul Tahun 2019}

Berdasarkan hasil wawancara bersama tiga orang informan dapat diketahui jika desa Sumberingin Kidul, Ngunut merupakan salah satu desa yang pada tahun 2019 turut mengadakan Pilkades serentak di Kabupaten Tulungagung. Dalam perhelatan pemilihan kepala desa yang ada di desa ini menurut informan menghadirkan dua orang calon kepala desa. Adapun dua orang calon ini juga pernah bersaing pada Pilkades tahun 2013. Calon kepala desa yang mencalonkan kembali pada tahun 2019 dari paslon nomor urut 1 bernama Arianto, dimana Arianto ini merupakan calon petahana yang kembali mencalonkan diri sebagai kepala desa Sumberingin Kidul. Sedangkan dari kubu penantang nomor urut 2 bernama Saifuddin yang oleh warga sekitar lebih akrab dipanggil dengan julukan kleker. 
Dalam proses Pilkades yang ada di desa Sumberingin Kidul Ngunut ini kedua calon saling berlomba-lomba dengan berbagai cara untuk menarik pemilih dan menarik perhatian dari warga masyarakat sekitar. Menurut dari penuturan informan sebelum Pilkades digelar sempat ada persaingan yang cukup sengit antar kedua kubu pasangan calon, hal itu mencapai puncaknya ketika hari $\mathrm{H}$ pada saat pemilihan, dimana pada saat itu tensi persaingan cukup memuncak dan memanas.

\section{Fenomena Praktik Politik Uang didalam Pilkades}

Dalam usahanya untuk menarik simpati dan menggalang suara dari pemilih, antara kedua pasangan calon kepala desa tersebut saling berlomba-lomba untuk menarik simpati warga dengan berbagai cara. Menurut keterangan dari informan antara kedua Paslon seringkali mengadakan jamuan makan malam bagi masyarakat dan sering juga mengadakan hiburan-hiburan seperti Orkes untuk masyarakat. Tidak hanya itu, untuk menarik simpati warga masyarakat lain, kedua pasangan calon kepala desa juga turut mengeluarkan politik uang untuk menyogok atau menyuap warga dengan tujuan agar pada saat hari $\mathrm{H}$ pemilihan mau memberikan hak pilihnya kepada calon yang memberinya uang. Menurut sepengetahuan informan, politik uang banyak beredar pada sekurang-kurangnya $\mathrm{H}-7$ hari pemilihan. Pada saat itu tim sukses setiap pasangan calon bergerak dari rumah ke rumah untuk mendata namanama yang akan diberi uang. Saat itu juga warga masyarakat diberi uang dengan syarat agar memilih paslon tertentu pada saat hari $\mathrm{H}$ pemilihan. Dari keterangan informan, kedua calon kepala Desa Sumberingin Kidul ini juga turut mengeluarkan politik uang masing-masing, akan tetapi jumlah kisaran uang yang diberikan kepada masyarakat dari kedua pasangan calon tersebut memiliki nominal yang berbeda-beda, informan turut menjelaskan jika dari calon petahana dari nomor urut satu juga mengeluarkan politik uang dengan kisaran 100 ribu hingga 200 ribu kepada setiap warga. Adapun dari kisaran ini setiap warga masyarakat memperolehnya dengan nominal yang tidak sama. Menurut informan ada yang mendapat 100 ribu, ada yang mendapat 150 ribu dan ada juga yang mendapat 200 ribu. Lebih lanjut informan mengatakan bahwa politik uang dari pasangan calon petahana nomor satu ini diberikan pada saat menjelang pemilihan atau pada pagi hari sebelum pencoblosan di TPS. Pagi hari itu tim sukses dari calon nomor urut satu bergerak dari rumah ke rumah untuk memberikan uang tersebut sesuai dengan catatan yang ada sebelum hari H. Dalam artian calon nomor urut satu ini masih menerapkan strategi serangan fajar untuk menarik pemilih. Tidak hanya itu, pesaing dari kubu nomor urut dua yakni dari calon Saifuddin juga turut memberikan politik uang kepada masyarakat. Namun menurut informasi dari informan ini jumlah kisaran uang yang diberikan lebih sedikit daripada yang diberikan oleh pesaingnya. Calon nomor urut dua ini memberikan politik uang dengan kisaran 50 ribu rupiah untuk perkepala namun dari calon nomor urut dua ini juga memberikan dalam bentuk barang seperti pemberian sajadah dan sarung kepada masyarakat. Namun cara pemberian yang diberikan oleh calon Kades nomor urut dua ini tidak sama dengan yang pertama. Pemberian politik uang ini diberikan bukan pada saat hari $\mathrm{H}$ pemilihan, akan tetapi diberikan pada saat $\mathrm{H}-3$ hari menjelang pemilihan.

Kedua cara pemberian politik uang dari kedua pasangan calon ini cukup berbeda namun pada akhirnya memiliki tujuan yang sama yakni untuk mendulang dukungan dari warga masyarakat sekitar. Tidak hanya kecurangan dalam bentuk politik uang saja yang ditemukan dalam penelitian ini, akan tetapi masih juga ditemukan bentuk kecurangankecurangan lain yang turut mewarnai pelaksanaan Pilkades Desa Sumberingin Kidul ini. Menurut informan juga terdapat proses jual beli surat suara dalam proses Pilkades ini. Kemudian, jual beli surat suara ini dilakukan pada pagi hari menjelang pemilihan, dimana 
yang menjadi sasaran ini yakni beberapa warga dari kalangan lansia yang ada di Desa Sumberingin Kidul. Para lansia ini kebetulan sangat buta politik mereka tidak bisa menentukan calon mana yang akan dipilih, oleh karena itu dari paslon nomor urut satu memiliki stategi untuk membeli surat suara mereka dengan harga yang cukup mahal. Menurut informan saat itu satu surat suara yang dibeli seharga kurang lebih 200 ribu. Adanya pembelian surat suara ini seakan menambah panjang lagi mengenai segala bentuk-bentuk kecurangan yang ada di Pilkades di desa Sumberingin Kidul ini.

\section{Persepsi Masyarakat Desa Sumberingin Kidul Mengenai Praktik Politik Uang}

Menurut keterangan dari informan, ketika peneliti tanyakan mengenai politik uang, salah satu dari informan menanggapi jika sebetulnya ia paham mengenai adanya sebuah pelarangan praktik politik uang didalam Pilkades, bahkan salah satu dari informan tersebut juga mengerti tentang adanya peraturan per-Undang-Undangan yang melarang terjadinya suap maupun praktik politik uang disana. Namun, ketika peneliti menanyakan mengenai apakah ia menerima uang pada saat Pilkades, informan menuturkan jika ia juga mendapat uang dari salah satu calon kepala desa. Informan turut menambahkan jika adanya sebuah praktik politik uang dalam sebuah kegiatan pemilihan umum merupakan suatu bentuk hal yang sangat wajar saat ini dan sudah bukan menjadi rahasia umum lagi. Informan pada saat itu mengaku tidak bisa menolak tawaran pemberian uang dari tim sukses salah satu calon. Hal ini dikarenakan menurut informan hal tersebut sangat "menggiurkan". Disatu sisi ia diberikan uang atau barang dalam jumlah yang besar dan hanya dimintai imbal balik dalam hal pemberian hak pilih suara. Kebanyakan masyarakat desa yang masih awam dan buta mengenai politik menganggap jika adanya praktik politik uang adalah hal yang biasa. Banyak dari mereka yang tidak menyadari jika adanya praktik politik uang ini dapat menciderai sistem demokrasi yang ada di Indonesia. Adanya praktik politik uang juga dapat mengubah demokrasi yang ada di Indonesia juga yang semestinya demokrasi berada di tangan rakyat berubah menjadi demokrasi berada di tangan orang berduit. Masyarakat desa Sumberingin Kidul ini menganggap jika adanya praktik politik uang merupakan suatu berkah tersendiri bagi mereka, bagaimana tidak, mereka banyak sekali diberi uang oleh tim sukses calon kepala desa dengan syarat agar memberikan hak pilih pada calon tertentu.

\section{Pembahasan}

Sesuai dengan yang telah diutarakan pada bagian konsep teori diatas, dalam penelitian ini menggunakan teori fenomenologi yang telah dicetuskan oleh Alfred Schutz. Menurut Schutz tindakan sehari-hari yang dilakukan oleh setiap individu ini pada dasarnya memiliki tujuan-tujuan yang hendak dicapai yang oleh Schutz sendiri disebut dengan In Order to Motive (motif tujuan). Tidak hanya itu Schutz juga mengemukakan konsepsinya mengenai Because of Motive yang artinya motif yang menjadi sebab terjadinya sebuah tindakan.

Adapun dari hasil temuan ini bila dianalisis lebih dalam menggunakan persepektif teori fenomenologi ini yakni sebuah fenomena politik uang yang terjadi dalam Pilkades yang ada di Desa Sumberingin Kidul ini pada dasarnya memiliki motif tujuan untuk mempengaruhi pilihan dari masyarakat. Adanya suatu praktik politik uang di dalam Pilkades juga memiliki tujuan-tujuan lain yakni untuk membeli suara dari masyarakat dan untuk menggiring massa dari sebagian penduduk desa. Sebagaimana dengan yang telah diketahui bersama bahwasanya masyarakat desa mayoritas masih belum menyadari akan pentingnya memilih suatu pemimpin yang baik. Dalam memberikan hak pilihnya mereka juga dapat dikatakan kurang rasional, yang mana dalam memberikan suatu pilihan masyarakat desa tidaklah melihat atau mempertimbangkan mengenai visi dan misi dari calon kepala desa yang ada, umumnya 
mereka hanya mau memilih jika ada upahnya atau diberi suatu imbalan material (Faulks, 2015). Hal ini seakan menjadi celah tersendiri bagi calon kepala desa untuk menghegemoni dan menggiring suara masyarakat lewat sebuah pemberian politik uang. Adanya salah satu bentuk kecurangan praktik politik uang didalam Pilkades Desa Sumberingin Kidul ini seakan menambah panjang catatan buruk mengenai sistem demokrasi dan perpolitikan yang ada di Indonesia. Bagaimana tidak, pada saat ini dimanapun tempatnya baik pada proses-proses Pilkades, Pilkada maupun Pemilu tidak menutup kemungkinan selalu diwarnai dengan adanya praktik-praktik politik uang. Pada masa kini nampaknya sebuah praktik politik uang menjadi suatu kebiasaan ataupun menjadi sebuah budaya yang selalu mewarnai kontestasi pemilihan politik.

Sedangkan apabila dianalisis menggunakan konsep Schutz yang lain yakni mengenai because of motive (motif sebab) hal ini berarti adanya praktik politik uang yang ada di Desa Sumberingin Kidul ini sejatinya terjadi juga karena adanya perebutan kekuasaan (power struggle) untuk menjadi pemimpin. Dalam artian ada suatu keinginan dari salah satu calon kepala desa untuk memenangkan sebuah kontestasi perpolitikan yang ada. Adapun untuk memenangkan suatu kontestasi dan untuk menarik perhatian masyarakat yang dirasa paling efektif salah satunya yakni menggunakan politik uang. Seperti yang telah diketahui bersama bahwa uang pada masa kini seolah menjadi daya tarik bagi masyarakat. Pada saat ini adanya praktik politik uang dirasa menjadi senjata ampuh untuk memenangkan proses pemilihan umum yang ada di masyarakat. Masyarakat desa dengan berbagai keterbatasan ekonomi menjadi suatu sasaran yang dituju untuk penyebaran politik uang ditambah lagi dengan adanya faktor kekurangtahuan masyarakat desa mengenai perpolitikan yang ada seakan menambah buruk mengenai sistem demokrasi yang ada di Indonesia.

\section{Kesimpulan}

Pilkades merupakan salah satu ajang politik yang dilaksanakan setiap kurang lebih enam tahun sekali. Perhelatan politik ini dilaksanakan untuk memberi akses kepada masyarakat desa untuk memilih pemimpin desa yang akan memimpin di periode ke depan. Dalam pelaksanaan Pilkades ini biasanya dilaksanakan secara serentak satu Kabupaten secara keseluruhan. Kabupaten Tulungagung pada tahun 2019 menjadi salah satu daerah yang turut menyelenggarakan Pilkades serentak. Dalam pelaksanaan Pilkades serentak yang ada di daerah ini masih juga diwarnai dengan berbagai hal-hal berbau kecurangan. Salah satunya seperti Pilkades yang ada di desa Sumberingin Kidul Kecamatan Ngunut, yang mana dalam Pilkades di desa ini masih diwarnai dengan praktik-praktik politik uang (money politics).

Fenomena praktik politik uang yang ada di Desa Sumberingin Kidul ini pada dasarnya terjadi untuk mempengaruhi pilihan dari masyarakat sendiri, dimana adanya uang menjadi daya tarik bagi masyarakat untuk memberikan pilihan pada calon tertentu. Uang pada saat ini dirasa menjadi media yang paling efektif untuk menghegemoni masyarakat dan menggiring massa untuk melakukan pilihan tertentu. Adanya suatu praktik politik uang sebenarnya sudah dilarang melalui peraturan per Undang-undangan namun pada masa kini masih banyak sekali ditemui ketika menjelang pemilihan. Secara tidak langsung dapat disadari jika adanya praktik politik uang ini dapat merusak sistem demokrasi yang ada. 


\section{Daftar Pustaka}

Amanu, M. (2015). Politik Uang dalam Pemilihan Kepala Desa ( Studi Kasus di Desa Jatirejo Kecamatan Banyakan Kabupaten Kediri). Jurnal Mahasiswa Sosiologi, 1(2), 1-24.

Ardianto, A. (2018). 235 Desa di Tulungagung Bakal Gelar Pilkades Serentak 2019. Diakses dari https://jatimnow.com/baca-7792-235-desa-di-tulungagung-bakal-gelar-pilkadesserentak-2019

Damsar, D. (2010). Pengantar Sosiologi Politik. Jakarta: Kencana Media Group.

Fahmi, Y. (2018). Motif Politik Dukungan Kiai NU Kediri Terhadap saifullah Yusuf Pada Pilgub Jatim 2018. Tesis. Universitas Airlangga

Faulks, K. (2015). Sosiologi Politik. Bandung: Nusamedia.

Maran, R. R. (2007). Pengantar Sosiologi Politik. Jakarta: Rineka Cipta.

Mukhsinin. (2018). Tindak Pidana Politik Uang Pemilihan kepala Desa dalam Perspektif Hukum Positif dan Hukum Islam (Studi Kasus di Desa Megonten Kec. Kebonagung Kab. Demak. Tesis. UIN Walisongo Semarang

Nuratika. (2015). Politik Uang Pemilihan Kepala Daerah di Desa Ketapang Permai dan Desa Tanjung Kulim Kabupaten Kepulauan Meranti Tahun 2015. JOM FISIP, 4(2), 1-15.

Putra, E. V. (2018). Money Politics dalam Penyelengaran Pemilihan Umum di Kota Pariaman. Jurnal Socius: Journal of Sociology Research and Education, 4(1), 1-16. https://doi.org/https://doi.org/10.24036/scs.v4i1.19

Susanto, E. (2018). Tulungagung Kucurkan Rp 15 Miliar Untuk Pemilihan Kepala Desa. Diakses dari https://nasional.tempo.co/read/1135746/tulungagung-kucurkan-rp-15miliar-untuk-pemilihan-kepala-desa 